\title{
Air Potato Leaf Beetle (Suggested Common Name), Lilioceris cheni Gressitt and Kimoto (Insecta: Coleoptera: Chrysomelidae: Criocerinae) ${ }^{1}$
}

\author{
Rodrigo Diaz, William A. Overholt, and Ken Hibbard ${ }^{2}$
}

\section{Introduction}

Air potato (Dioscorea bulbifera L., Dioscoreaceae) is a herbaceous, perennial twining vine that attains lengths of $20 \mathrm{~m}$ or more, rendering it capable of climbing over and smothering native vegetation (Schmitz et al. 1997, Overholt et al. 2008, Figure 1).

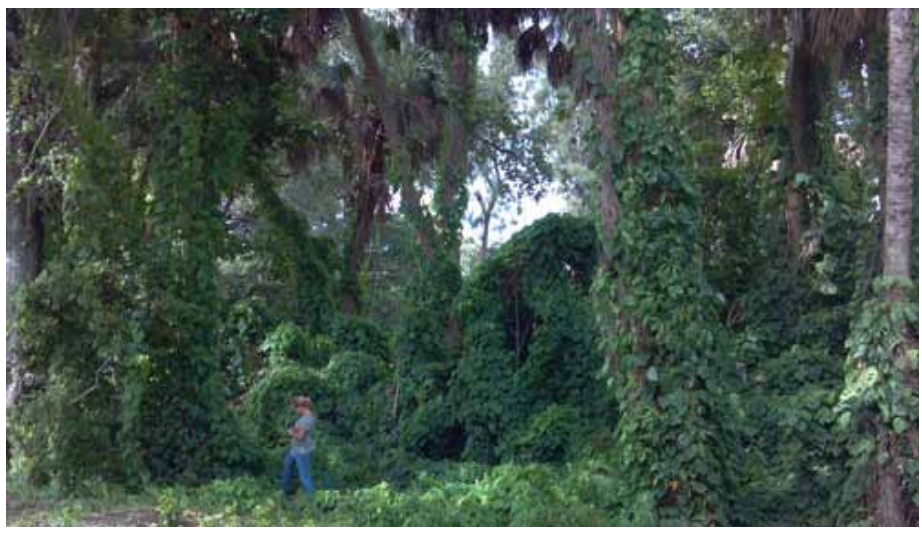

Figure 1. Air potato infestation at Snyder Park in Fort Lauderdale. Credits: Ted D. Center, USDA/ARS Invasive Plant Research Laboratory, Fort Lauderdale, FL.

The native range of air potato includes much of Asia and Africa, and recent molecular evidence suggests that air potato in Florida originated from China (Croxton et al. 2011). Air potato was introduced to Florida in 1905 when it was sent to the USDA by Henry Nehrling, who later noted its invasive potential (Morton 1976). It has since become extremely aggressive (Hammer 1998). By the 1980s, air potato vines were growing in thickets, waste areas, and hedges or fencerows in many parts of south and central Florida (Bell and Taylor 1982). By 1999, air potato was recognized as an invasive exotic that alters plant communities by displacing native species, changing community structure, and disrupting ecological functions (FLEPPC 2003). A leaf feeding beetle, Lilioceris cheni, was recently introduced into Florida from China for biological control of air potato.This article provides information on the distribution, appearance, life cycle, host range and importance of the beetle.

\section{Distribution}

The air potato leaf beetle is native to Asia. Country records include China, India, Nepal, Laos, and Thailand (Kimoto and Gressitt 1979, Tishechkin et al. 2011). The beetle was first released in Florida in 2012 for biological control of air potato.

\section{Description}

\section{Adult}

Lilioceris cheni adults are about $9 \mathrm{~mm}$ long and $4 \mathrm{~mm}$ wide. The color of the elytra ranges from brown to orange or red, and the abdomen, thorax, head, and legs are black. The

1. This document is EENY-547, one of a series of the Entomology and Nematology Department, Florida Cooperative Extension Service, Institute of Food and Agricultural Sciences, University of Florida. Original publication date January 2013. Visit the EDIS website at http://edis.ifas.ufl.edu.

2. Rodrigo Diaz, William A. Overholt, and Ken Hibbard, Department of Entomology and Nematology; Florida Cooperative Extension Service, Institute of Food and Agricultural Sciences, University of Florida, Gainesville, FL 32611 
beetle is elongate, with a rectangular-shaped abdomen, a thorax about half as wide as the abdomen, and a narrow head with bulging eyes. The shape somewhat resembles a square violin with a short neck (Figure 2).

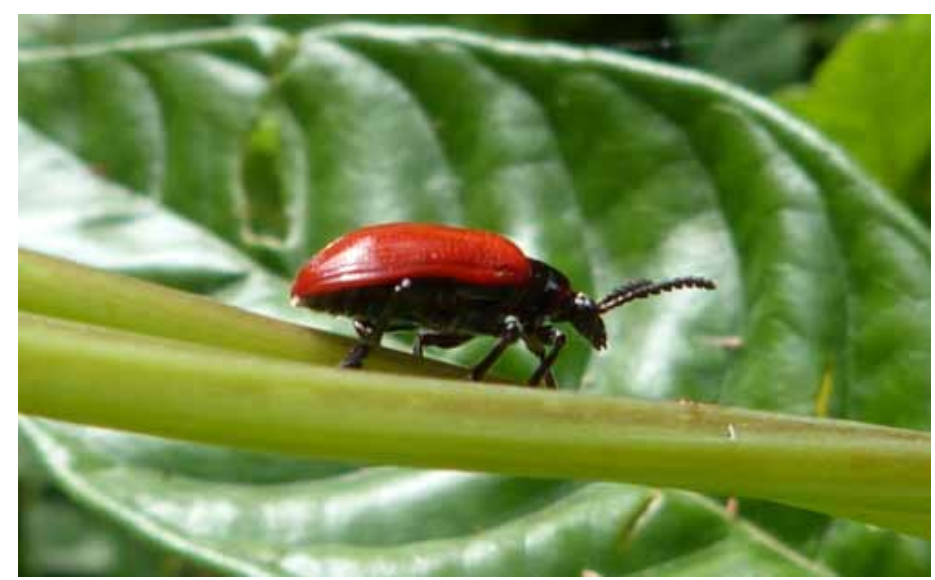

Figure 2. Adult Lilioceris cheni.

Credits: Ted D. Center, USDA/ARS Invasive Plant Research Laboratory, Fort Lauderdale, FL.

\section{Egg}

Pale white, oblong and about $1 \mathrm{~mm}$ in length. Eggs become yellowish as the embryo develops (Figure 3 ) and hatch after four days.

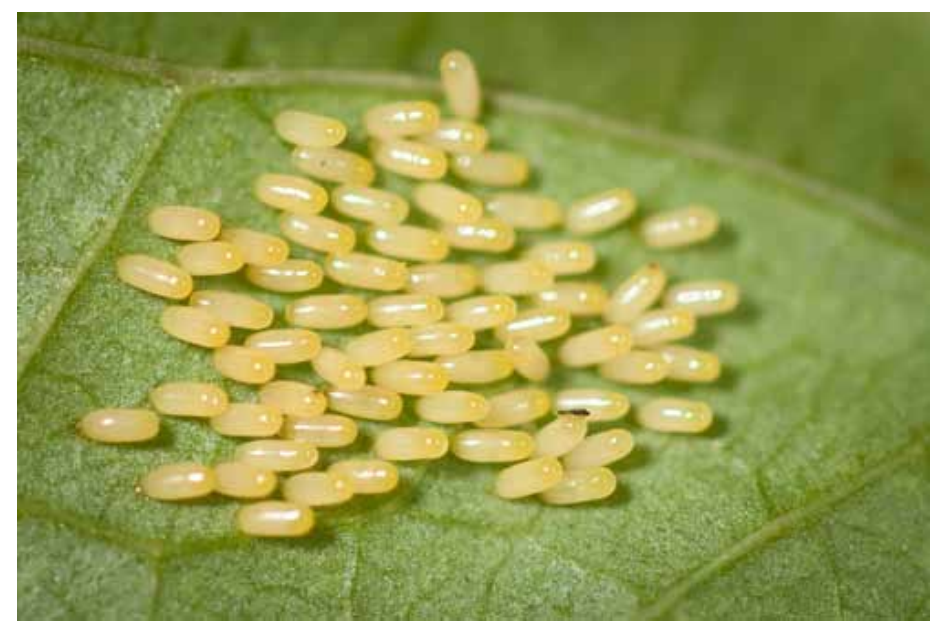

Figure 3. Lilioceris cheni eggs.

Credits: Melissa C. Smith, USDA/ARS Invasive Plant Research Laboratory, Fort Lauderdale, FL.

\section{Larva}

There are four larval instars. First instars are yellowish to reddish (Figure 4), and later instars are grayish to reddish, with black legs, head capsule, and prothoracic shield (Figure 5). Larvae are often covered with a sticky secretion to which fecal material adheres.

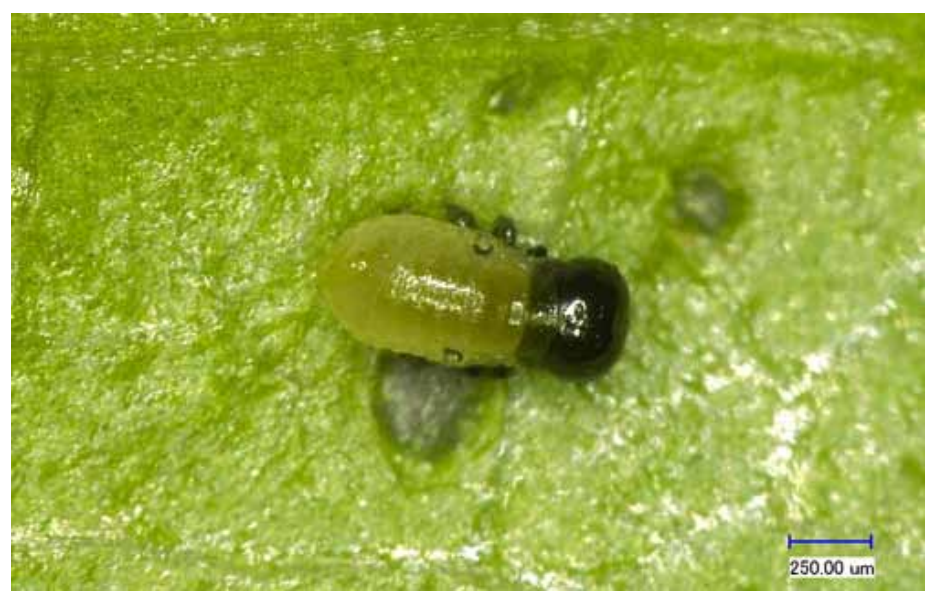

Figure 4. Lilioceris cheni first instar.

Credits: Gloria L. Witkus, USDA/ARS Invasive Plant Research

Laboratory, Fort Lauderdale, FL

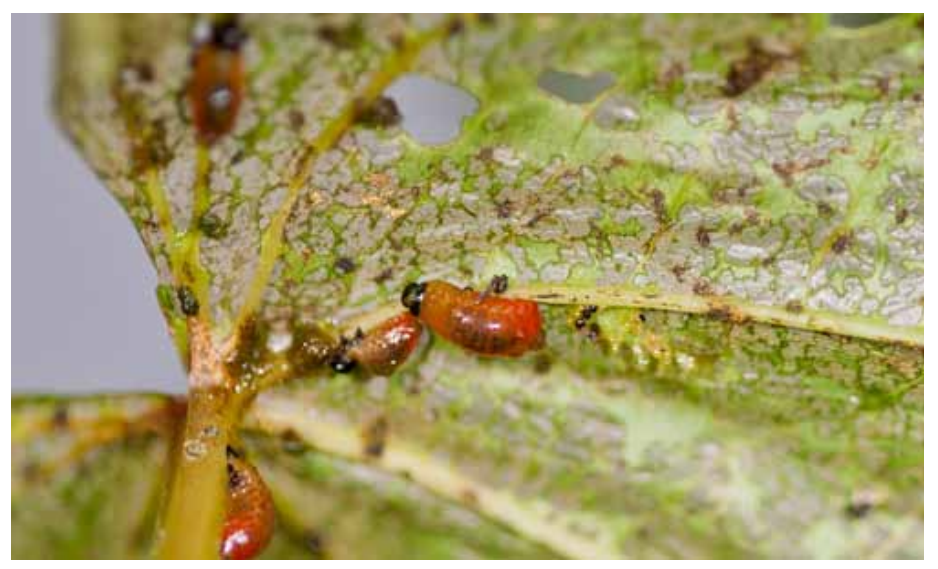

Figure 5. Lilioceris cheni late instar larva

Credits: Melissa C. Smith, USDA/ARS Invasive Plant Research Laboratory, Fort Lauderdale, FL.

\section{Pupa}

Fully grown larvae enter the soil and produce a whitish oral secretion that hardens into a foam-like cocoon that is about $7 \mathrm{~mm}$ in length. Pupation occurs gregariously, often with several pupae clumped together within a matrix of the foam-like material that becomes covered with soil and other substances (Figures 6 and 7).

\section{Life Cycle and Biology}

Females deposit pale white, oblong eggs in loosely aggregated clusters on the undersides of young, expanding leaves of air potato. The process of oviposition apparently deforms the expanding leaf causing it to curl at the edges becoming cup-like around the eggs (Figure 8).

Females deposit more than 1200 eggs on average during their lifetime. The eggs become yellowish as the embryo develops, and dark reddish eye spots appear mid-way through the incubation period. Embryonic development 


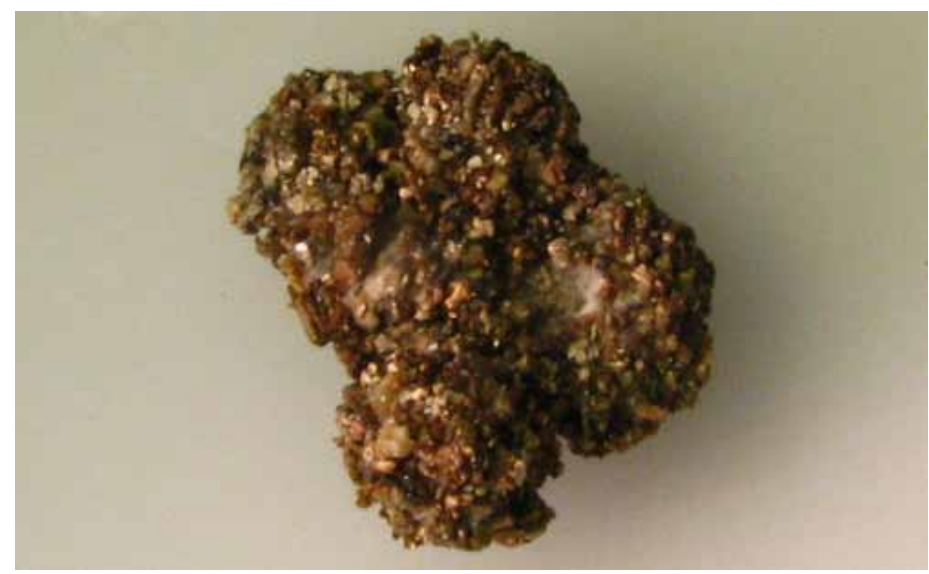

Figure 6. Lilioceris cheni pupal aggregation covered with soil particles. Credits: William A. Overholt, UF/IFAS Indian River Research and Education Center, Fort Pierce, FL.

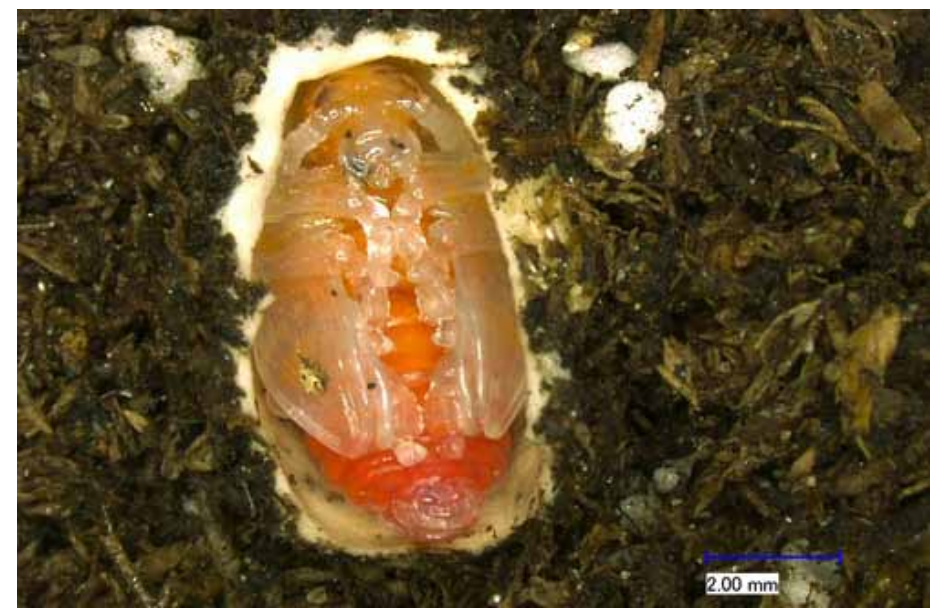

Figure 7. Lilioceris cheni pupa within a partially removed cocoon. Credits: Gloria L. Witkus, USDA/ARS Invasive Plant Research Laboratory, Fort Lauderdale, FL

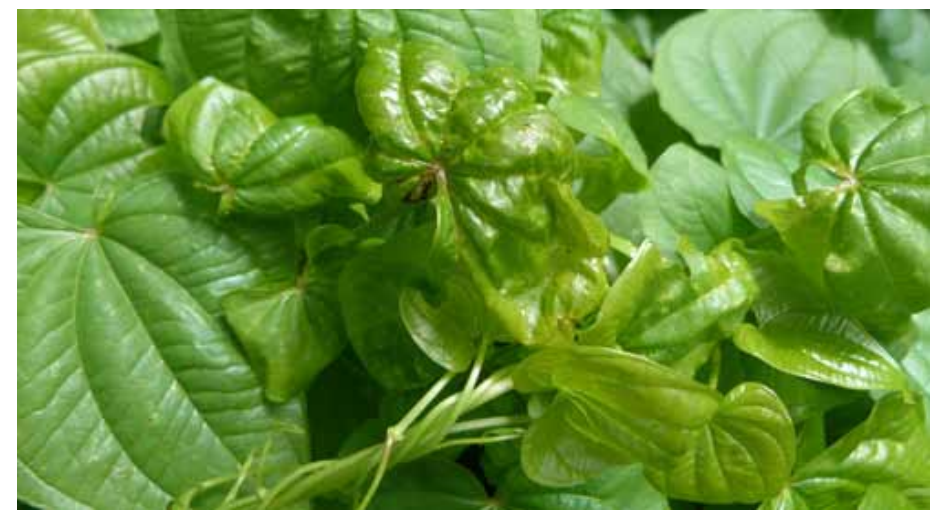

Figure 8. A deformed expanding air potato leaf.

Credits: Ted D. Center, USDA/ARS Invasive Plant Research Laboratory, Fort Lauderdale, FL.

requires about four days. Larvae feed gregariously and skeletonize the leaves from the underside (Figures 9).

Young tender leaves are preferred but they also consume older, tougher leaves and are able to feed on the aerial

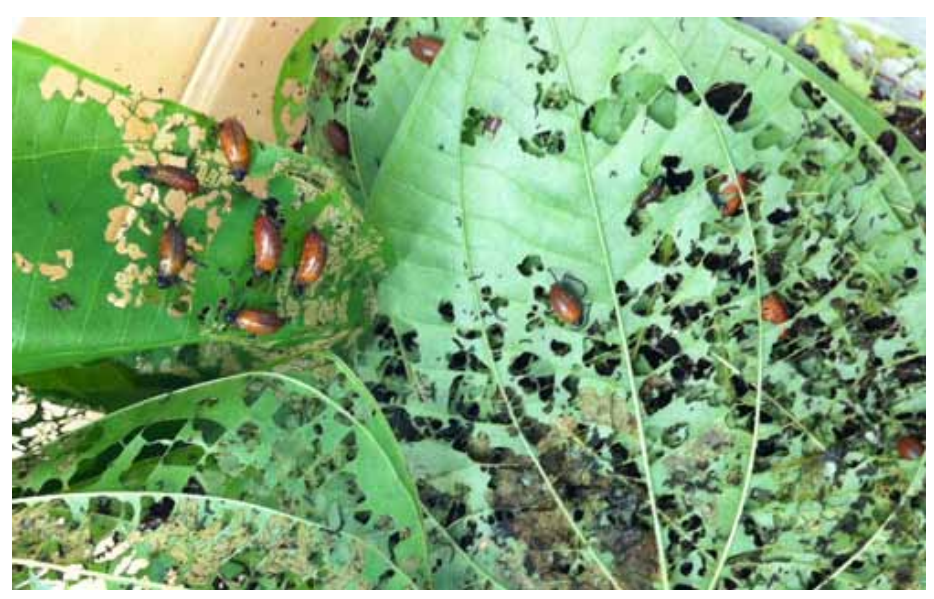

Figure 9. An aggregation of late instar Lilioceris cheni larvae skeletonizing air potato leaves.

bulbils. Complete development of the four instars requires about eight days, with each stage lasting about two days. When fully grown, larvae descend from the host plant and enter the soil where they produce a whitish oral secretion that hardens into a foam-like cocoon. Pupation occurs gregariously, often with several pupae clumped together within a matrix of this material. Adults emerge in 12 to 16 days, begin mating after about 10 days, and initiate oviposition five days later. The adults live for five months or longer. Both adults and larvae feed on the foliage.

Larvae can often be found in aggregations on the growing tips of air potato vines. The host plant senesces during the winter, forcing the adult beetles to go several months without food, presumably in diapause beneath leaf litter and other debris. The overwintered adults emerge in the spring, and females begin laying eggs.

\section{Host}

Extensive host range testing by scientists at the USDA/ ARS Invasive Plant Research Laboratory in Fort Lauderdale demonstrated that the air potato leaf beetle is a specialist feeder on air potato. It will not complete development on any other plant found in Florida and is only known to feed on Dioscorea bulbifera in its native range (Pemberton and Witkus 2010).

\section{Importance}

Larvae and adults of the air potato leaf beetle consume leaf tissue and occasionally feed on bulbils, thereby negatively affecting plant growth and reproduction. Damage to growing tips inhibits vine elongation and may reduce the ability of air potato to climb vertical structures. At initial release 
sites, extensive damage to air potato was evident within three months after the first release.

Although it is too early to determine the long-term impacts of the beetle on air potato, initial results are very promising. If you think you have found this beetle in your area, please send a photograph for identification along with locality data (GPS coordinates preferred) to Paul.Pratt@ars.usda.gov and we will add this information to our locality map.

\section{Selected References}

Bell CR, Taylor BJ. 1982. Florida Wild Flowers and Roadside Plants. Laurel Hill Press, Chapel Hill, N.C.

Croxton MD, Andreu MA, Williams DA, Overholt WA, Smith JA. 2011. Geographic origins and genetic diversity of air-potato (Dioscorea bulbifera) in Florida. Invasive Plant Science and Management 4: 22-30.

FLEPPC Plant List Committee. 2003. Florida Exotic Pest Plant Council's 2003 list of invasive species. (27 August, 2012).

Hammer RL. 1998. Diognosis: Dioscorea. Wildland Weeds 2: 8-10.

Kimoto S, Gressitt JL. 1979. Chrysomelidae (Coleoptera) of Thailand, Cambodia, Laos and Vietman. I. Sagrinae, Donaciinae, Zeugophorinae, Melapodinae and Criocerinae. Pacific Insects 20: 191-256.

Morton JF. 1976. Pestiferous spread of many ornamental and fruit species in south Florida. Proceedings Florida State Horticultural Society 89: 348-353.

Overholt WA, Markle L, Meisenburg M, Raz L, Wheeler G, Pemberton R, Taylor J, King M, Schmitz D, Parks GR. 2008. Air Potato Management Plan. Florida Exotic Pest Plant Council. (27 August, 2012).

Pemberton RW, Witkus GL. 2010. Laboratory host range testing of Lilioceris sp. near impressa (Coleoptera: Chrysomelidae) - a potential biological control agent of air potato, Dioscorea bulbifera (Dioscoreaceae). Biocontrol Science and Technology 20: 567-587.

Schmitz DC, Simberloff D, Hofstetter RL, Haller WT, Sutton D. 1997. The ecological impact of nonindigenous plants, pp. 39-61. In Simberloff D, Schmitz DC, Brown TC (editors), Strangers in Paradise: Impact and Management of Nonindigenous Species in Florida. Island Press, Washington, D.C. 467 pp.
Tishechkin AK, Konstantinov AS, Bista S, Pemberton RW, Center TD. 2011. Review of the continental Oriental species of Lilioceris Reitter (Coleoptera, Chrysomelidae, Criocerinae) closely related to Lilioceris impressa (F.). ZooKeys 103: 63-83. 